\title{
DETERMINATION OF THE FUNCTIONAL AND SERVICE CHARACTERISTICS OF THE PNEUMATIC SYSTEM OF AN AGRICULTURAL TRACTOR WITH MECHANICAL BRAKES USING SIMULATION METHODS
}

\section{WYZNACZANIE METODAMI SYMULACYJNYMI WŁAŚCIWOŚCI FUNKCJONALNO- UŻYTKOWYCH PNEUMATYCZNEJ INSTALACJI CIĄGNIKA ROLNICZEGO Z HAMULCAMI MECHANICZNYMI*}

\begin{abstract}
Agricultural tractors are provided with air braking systems to control and operate braking systems of towed agricultural vehicles. Functional and operational characteristics of the tractor pneumatic system have a significant influence on the synchrony and operate speed of tractor-trailer unit braking system. This paper presents a mathematical model to predict the functional and operational characteristics of tractor pneumatic system by using a digital simulation. Modeling of the energy supplying device (compressor, governor, air reservoir) and modeling of the control device with trailer control valve mechanically connected with the tractor brakes is described. Results of statistical Kolmogorov-Smirnov test used to assess the conformity of experimental and simulated pressure transients during testing the compressor capacity and the response time of control circuit of Pronar 320AM tractor confirmed the computer model developed in Matlab-Simulink. The computer model can be used as a tool to assess the functional and operational characteristics of tractor pneumatic system within the designing process and as a subsystem to analyze transient processes in a pneumatic braking systems of the tractor-trailer units by using simulation methods. Mathematical models of selected components can be also used in modeling other pneumatic braking systems of commercial vehicles.
\end{abstract}

Keywords: farm tractor, pneumatics, braking system, energy-supplying device, trailer control valve, modeling, simulation.

\begin{abstract}
Ciagniki rolnicze sa wyposażone w powietrzne instalacje hamulcowe do sterowania i napędu układów hamulcowych pojazdów ciagnionych. Właściwości funkcjonalno-użytkowe instalacji pneumatycznej ciagnika maja istotny wpływ na synchronię i szybkość działania uktadu hamulcowego zespolu ciagnik-przyczepa. W niniejszej pracy przedstawiono model matematyczny do prognozowania właściwości funkcjonalno-użytkowych układu pneumatycznego ciagnika metoda symulacji cyfrowej. Opisano modelowanie zespolu zasilającego (sprężarka, regulator, zbiornik powietrza) i modelowanie zespołu sterującego z zaworem sterujacym hamulcami przyczepy połaczonym mechanicznie z hamulcami ciagnika. Wyniki testu statystycznego Kotmogorowa-Smirnowa oceny zgodności doświadczalnych i symulowanych przebiegów czasowych ciśnienia podczas badania wydatku sprężarki i czasu reakcji obwodu sterującego ciagnika Pronar 320AM potwierdziły adekwatność opracowanego w Matlabie-Simulinku modelu komputerowego. Model komputerowy może być wykorzystany jako narzędzie do oceny właściwości eksploatacyjno-użytkowych instalacji pneumatycznej ciagnika w procesie projektowania oraz jako podsystem do analizy metodami symulacyjnymi procesów przejściowych w pneumatycznych układach hamulcowych zespołów ciagnik-przyczepa. Modele matematyczne wybranych komponentów instalacji moga być również wykorzystane w modelowaniu innych pneumatycznych układów hamulcowych pojazdów użytkowych
\end{abstract}

Stowa kluczowe: ciagnik rolniczy, pneumatyka, układ hamulcowy, zespót zasilajacy, zawór sterujący hamulcami przyczepy, modelowanie, symulacja.

\section{Introduction}

In agricultural tractors, a variety of friction braking mechanisms are used, including band brakes, drum brakes, and dry or wet multidisc brakes [5]. To transfer the energy needed to run the service brakes of a tractor, a mechanical, hydraulic or an air drive is used. Selection of the drive type and the energy source depends on the design and weight of the tractor. In low- and medium-power tractors, manually operated hydraulic brake systems are used, which are relatively inexpensive and simple. Because of their cost, mechanically actuated brakes are still attractive in low-power tractors.

Agricultural tractors with mechanical or hydraulic brakes are equipped with a pneumatic system designed to run the air braking sys- tems of towed trailers and agricultural machines. So called combined systems are currently used [32], which have the capability to operate with the single- and dual-line braking systems of towed vehicles.

A typical combined pneumatic system of a farm tractor consists of two major parts: an energy supply unit and a control device. The function of the energy supply unit is to compress and purify air and to maintain the adequate pressure in the tractor and trailer reservoirs in order to ensure the required trailer braking performance. The role of the control device is to provide the follow-up control of the single- or dual-line braking system of a towed vehicle in a manner that enables the synchronous braking of the both vehicles. Control devices differ mainly in the type of the trailer brake control valve, which can be actuated either mechanically, hydraulically or pneumatically, de-

(*) Tekst artykułu w polskiej wersji językowej dostępny w elektronicznym wydaniu kwartalnika na stronie www.ein.org.pl 
pending on the tractor brakes [32]. A schematic diagram of a tractor's pneumatic system with a mechanically actuated brake valve is shown in Figure 1.

Because of the road safety, agricultural vehicles braking systems must meet several specific requirements $[8,9]$ for braking performance, high operation speed during rapid braking (the response time should not exceed $0.6 \mathrm{~s}$ ) and the compatibility of the tractor and towed vehicle braking systems [27] (the synchrony of operation of individual circuits). Research by Scarlett [28] reveals that 90\% tested trailers failed to achieve the legally required braking efficiency level. The incompatibility of the tractor and trailer brake systems resulting in jackknifing or skidding during braking was the cause of approximately $9.7 \%$ of the fatalities in the UK in the period 1999-2004 [7].

The functional and service characteristics of brake systems, including dynamic characteristics that determine the speed and synchrony of action, may be predicted already at an early stage of design using digital simulation methods. This requires the development of mathematical and computer models for individual devices of the braking system. In the process of modelling, the pneumatic elements are substituted with idealized elements in the form of lumped volumes and resistances $[18,20]$. Due to the discrete nature and complexity of braking systems, even components with parameters distributed in a continuous manner, such as pneumatic lines, are substituted with models of lumped parameters in mathematical modelling [14]. Discretization in space yields a system of ordinary differential equations, which can be solved using specialized software designed for simulation of complex engineering systems, including object-oriented software [34]. The advantage of model-based design is the increased the speed and efficiency of testing new solutions, the possibility of comparing them against the established requirements, and the earlier detection of any errors resulting from malfunctioning or incorrect design assumptions, as compared to the construction of physical prototypes.

The main difficulty in modelling the agricultural tractor pneumatic system is the lack of appropriate models for basic components in the literature, including air compressors and brake valves. Mathematical models for estimating the compressor performance and the thermodynamic behaviour of compressors under different working conditions $[2,10,30]$ are too complex for modelling of the dynamics of multicircuit pneumatic and hydraulic braking systems. In turn, most of the models known from the literature concerns the typical brake valves used in the air braking systems of commercial vehicles [11, 23, 29] and trailers [12, 13, 15, 21, 24].

In this paper, the functional and structural mathematical model of the pneumatic system of a small-power agricultural tractor is presented. Modelling of the trailer brake control valve serving for controlling dual-line trailer brake systems in conjunction with mechanical foot brakes of tractors is described in detail. The mathematical and computer model of this valve considers a number of phenomena, such as heat exchange, the inertia of movable elements, and friction, which are generally omitted already at the stage of physical creation or at the stage of running the computer model for digital simulation $[11,23,29]$. Whereas, in the case of modelling the energy supply unit described in [16], the most important final model equations are only given. A computer program implemented in Matlab-Simulink was used to estimate selected functional and service characteristics, including the assessment of supply unit compressor performance and the control device response time in accordance to the requirements for brake systems. The simulation results were compared with the results of experimental tests carried out under the same conditions. The developed model can be used in the process of designing a tractor's braking system at the stage of dynamic calculations. It can also be utilized as a subsystem in the simulation of transient processes in the pneumatic braking system of a tractor-trailer unit.

\section{Experimental setup for testing the tractor pneumatic braking system}

A simplified schematic diagram of the normal-pressure combined pneumatic braking system of a Pronar 320AM agricultural tractor [26] equipped with a mechanical brakes drive is shown in Figure 1. The energy supply unit includes filter 1 , air compressor 2 , unload valve (governor) 3, and compressed air reservoir 4. In high-pressure systems with a compressor discharge pressure of up to 18 bar, a pressure limiting valve (pressure reducer) is additionally installed downstream the air reservoir. Compressed air is also fed through a 4-way cross fitting to the control device, which includes proportional brake valve 11 and inverse brake valve brake 7 . Trailer control valve 11 is connected, via mechanism 12, with the tractor brake pedal. The driver's foot pressure on the treadle, transferred to valve 11 by a linkage system, causes the opening of the valve and a pressure increase in the line with coupling head 10 controlling the dual-line trailer braking system. The trailer braking system supply line is connected to coupling head 9 . For controlling the single-line trailer braking system, inversion valve 7 is used, which, on the increase of pressure in control port 4, causes a pressure drop in the supply and control line with coupling head 8 .

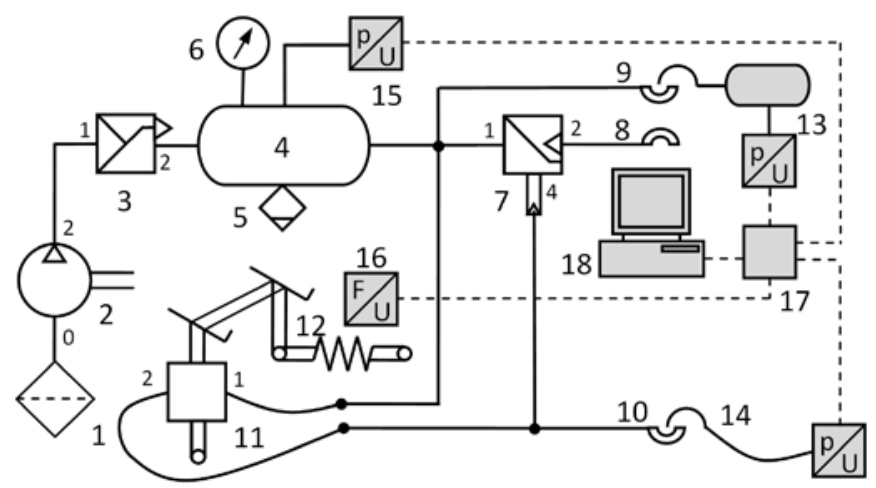

Fig. 1. Schematic diagram of the normal-pressure combined single-and dualline air braking system of a Pronar MTZ 320AM farm tractor with the experimental setup for testing the control line response time: 1 -filter, 2-601.23.944 compressor by FOS Polmo Łódź, 3- 5110018 unloader valve by Visteon, $4-10 \mathrm{dm}^{3}$ air reservoir, 5 -drain valve, 6-single pressure gauge, 7 -inversion trailer control valve, 8 - "single-line" coupling head (black), 9- "supply" coupling head (red), 10 - "brake" coupling head (yellow), 11 - 4113014 trailer brake control valve by Visteon (the primary section used), 12 - valve applying mechanism, $13-0,385 \mathrm{dm}^{3}$ air vessel, $14-2.5 \mathrm{~m}$-long $13 \mathrm{~mm}$-internal diameter pipe, 15 -pressure transducer, 16-pedal force transducer, 17 -input/ output adapter, 18 - computer with a measuring card

In Figure 1, the experimental setup, in the version for testing the response time of the tractor dual-line pneumatic system control device, is distinguished by the grey background. Changes in the force on the brake pedal and in pressure in selected locations of the pneumatic system are recorded by a measuring system consisting of voltage transducers 15 and 16, adapter 17, and a Senga MC1212 measuring card (12 bit resolution) mounted on computer 18 for data collection during tests being run. Tensometric brake pedal force sensor 16, type CL 23, with an industrial amplifier, type CL10D, manufactured by ZEPWN (with a measuring range of $0 \div 1 \mathrm{kN}$; an output signal range of $0 \div 10 \mathrm{~V}$; and an accuracy class of $0.1 \%$ ) is used for measuring the force on the brake pedal. The pressure is measured with industrial pressure transducer 10, type Danfoss MBS 32 (with a pressure range of $0 \div 10$ bar; an output range of $0 \div 10 \mathrm{~V}$; and an accuracy class of $0.3 \%$ ). The transducers are voltage supplied from input/output adapter 17. Output voltage signals from the force-pressure transducers are acquired from input/ output adapter 17 using the measuring card and then directly converted into force and pressure data with the use of integrated software 
installed on the computer. The maximum rpm of engine are measured with digital tachometer DMT-21 (with a measuring range: $0-9999$ rpm, an accuracy class of 0.2). Sample runs of registered changes of force and pressure during measuring a response time in steering unit of Pronar 320AM tractor are shown in Figure 5 and 6.

\section{Modelling of the mechanically actuated trailer brake control valve}

In the control circuit of the Pronar 320AM tractor's pneumatic system, the primary section of the Visteon 4113014 main foot brake valve [31] was used as trailer control valve 11 (Figure 1). This valve, normally used in dual-circuit air brake systems, is coupled with a linkage system operated by the treadle in the cabin. A schematic diagram of the structure of the valve, for the modelling purposes reduced to a single circuit, is given in Figure 2.

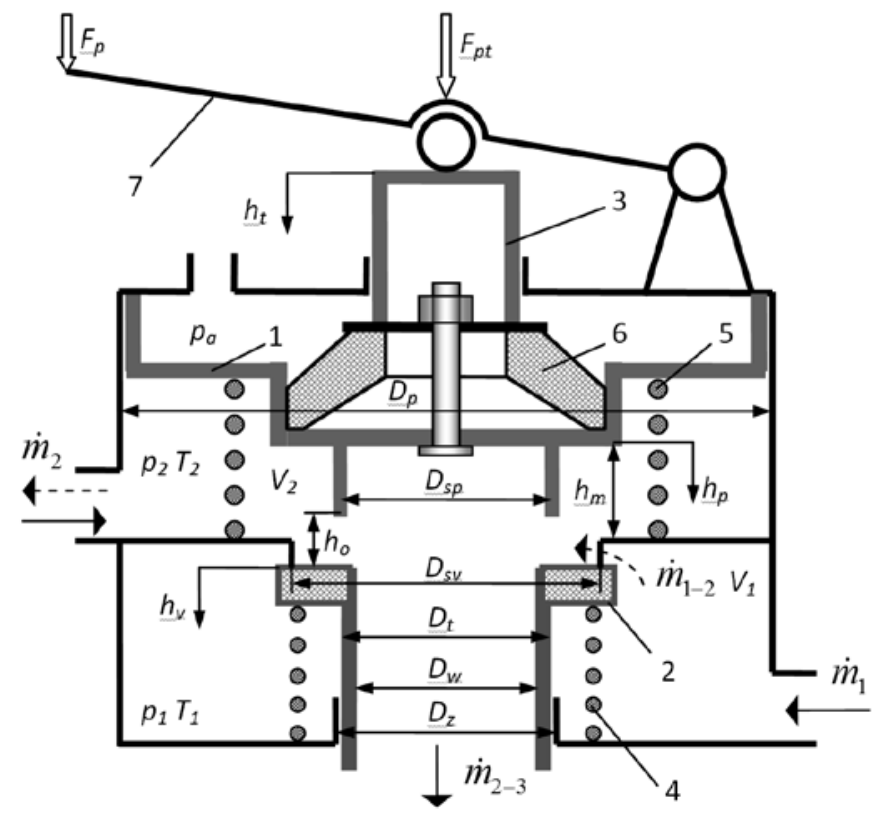

Fig. 2. A mechanically actuated trailer brake control valve: 1 - control piston, 2 -inlet head, 3 -tappet, 4 - head spring, 5-piston return spring, 6-rubber spring, 7 - actuating linkage

The air mass flux $\dot{m}_{1}$ flows into a fixed-volume inlet chamber $V_{l}$ from the supply circuit. During braking, control piston 1, moving downward by the action of force $F_{p}$ on the brake pedal, transferred via linkage 7 to tappet 3, opens inlet head 2. Compressed air from the inlet chamber flows into a variable-capacity outlet chamber $V_{2}$ as a mass flux $\dot{m}_{1-2}$. The flux $\dot{m}_{2}$ flowing from the outlet chamber $V_{2}$ is routed to the control circuit of the trailer braking system, resulting in activation of the trailer brakes. During the brake release caused by the decrease in the brake pedal force, the pressure in the chamber $V_{2}$, in combination with the force of spring 5 , raises piston 1 again. By the action of return spring 4, poppet valve 2 closes (cutting off the inlet chamber from the outlet chamber), and the passage between the seat in piston 1 and head 2 opens. The outlet chamber $V_{2}$ is vented. The compressed air from the control line returns to the outlet chamber as the mass flux $\dot{m}_{2}$ (flow reversal), and then flows out to the atmosphere as the mass flux $\dot{m}_{2-3}$. The venting of the outlet chamber and the control line causes a drop in the trailer brake force.

When creating the current mathematical model of the trailer control valve, a number of simplifying assumptions were made [15], including the following:
- Compressed air was regarded as a thermodynamically ideal gas (i.e. obeying the Clapeyron law), while being viscous and compressible.

- The valve adjusting element, irrespective of its design, was regarded as a local resistance (nozzle), whose effective flow field (conductance) depended on the head lift.

- The airflow through the adjusting element was considered onedimensional and adiabatic.

- The air properties were assumed to be uniform both in the individual valve chambers and in the entire cross-section of flow through the local resistance.

- In the valve opening phase, the force interaction between the head and the control piston was omitted, which means that both elements moved together as a single mass (one equation of motion).

- The air leakage in the valve chambers were neglected.

- The influence of the housing on the control piston in its end position was neglected; stopping of the piston was accomplished via the acceleration control logic (hard stopping).

- The heat exchange between the system's air and the environment took place by natural convection at a constant wall temperature which was equal to ambient temperature.

In accordance with the law of conservation of matter, the masse changes in the inlet chamber of volume $V_{l}$ (Figure 2) and the outlet chamber of volume $V_{2}$ are described by the equations:

$$
\begin{gathered}
\frac{d m_{V 1}}{d t}=\dot{m}_{1}-\dot{m}_{1-2} \\
\frac{d m_{V 2}}{d t}=\dot{m}_{1-2} \mp \dot{m}_{2}-\dot{m}_{2-3}
\end{gathered}
$$

where: $\dot{m}_{i}-$ the mass flux $(\mathrm{kg} / \mathrm{s})$ flowing into (the sign + ) or from (the sign -) a given chamber; the respective flux subscripts conform to the convention on denoting the braking valve chamber ports (the small numerals at the valve ports in Figure 2).

For the description of the air mass flux flow through the local pneumatic resistances, the Saint-Venant-Wantzel relationship [3] in the following generalized form was used:

$$
\dot{m}=\left(\mu A_{m}\right) \frac{p_{m}}{\sqrt{R T_{m}}} \psi_{\max } \psi(\sigma)
$$

where: $\left(\mu A_{m}\right)$ - conductance, i.e. the product of the discharge coefficient $\mu$ and the flow cross-section area $A_{m}\left[\mathrm{~m}^{2}\right], p_{m}$ - pressure [Pa] upstream of the resistance, $T_{m}$ - the air temperature $[\mathrm{K}]$ upstream of the resistance, $R$ - gas constant for air, being equal to $288[\mathrm{~J} /(\mathrm{kgK})]$, $\Psi_{\max }-$ maximum value of the Saint-Venant - Wantzel function for the critical pressure ratio $\sigma^{*}$ (product of the pressures upstream and downstream of the resistance), which is given by:

$$
\psi_{\max }=\psi\left(\sigma^{*}\right)=\sqrt{\kappa\left(\frac{2}{\kappa+1}\right)^{\frac{\kappa+1}{\kappa-1}}}=0.68473
$$

where : $\kappa$-adiabatic exponent, for air being equal to $\kappa=1.4$. Instead of the dimensionless two-range Saint - Venant flow function $\Psi(\sigma)$ as given by: 


$$
\Psi(\sigma)=\left\{\begin{array}{cl}
1 & \text { for } \sigma \leq \sigma^{*} \\
\frac{1}{\Psi_{\max }} \sqrt{\frac{2 \kappa}{\kappa-1}\left(\sigma^{\frac{2}{\kappa}}-\sigma^{\frac{\kappa+1}{\kappa}}\right)} & \text { for } \sigma^{*}<\sigma \leq 1
\end{array}\right.
$$

a single-range hyperbolic function [20, 22] was used, as being more convenient for numerical computation and yet sufficiently accurate:

$$
\psi(\sigma)=b \frac{1-\sigma}{b-\sigma}
$$

A constant parameter value of $b=1.13$, which is typical of the pneumatic elements used in the braking systems of vehicles, was assumed.

Using equation (3), the equations of mass fluxes flowing through the braking valve are obtained as:

$$
\begin{gathered}
\dot{m}_{1-2}=\mu_{12} A_{12} \frac{p_{1}}{\sqrt{R T_{1}}} \psi_{\max } \psi\left(\frac{p_{2}}{p_{1}}\right) \\
\dot{m}_{2-3}=\mu_{23} A_{23} \frac{p_{2}}{\sqrt{R T_{2}}} \psi_{\max } \psi\left(\frac{p_{a}}{p_{2}}\right)
\end{gathered}
$$

The flow cross-section areas $A_{12}$ (during braking) and $A_{23}$ (during releasing) are dependent on the piston travel $h_{p}$ and the distance $h_{v}$ of head 2 from the valve seat and are given by:

$$
\begin{gathered}
A_{12}=\left\{\begin{array}{ccc}
0 & \text { if } & h_{v} \leq h_{v o} \\
\frac{\pi D_{s v}\left(h_{v}-h_{v o}\right)}{\pi\left(D_{s v w}^{2}-D_{s p z}^{2}\right)} & \text { if } & h_{v o}<h_{v} \leq h_{v m} \\
4 & \text { if } & h_{v}>h_{v m}
\end{array}\right. \\
A_{23}=\left\{\begin{array}{ccc}
\pi D_{s p}\left(h_{o}-h_{p o}-h_{p}\right) & \text { if } & h_{p m} \leq h_{p}<h_{o}-h_{p o} \\
\frac{\pi D_{w}^{2}}{4} & \text { if } & h_{p}<h_{p m}
\end{array}\right.
\end{gathered}
$$

where: $D_{s v}, D_{s v w}$ - stationary seat average diameter [m] and inner diameter [m], respectively; $D_{s p z}-$ moveable seat outer diameter [m] (in the piston); $h_{v o}, h_{v m}$ - head 2 position [m] corresponding to the beginning of opening (allowing for plate seal deformation) and position $[\mathrm{m}]$ corresponding to attaining the maximum flow field value, respectively; $D_{s p}$ - the average diameter [m] of the moveable seat, $D_{t}$, $D_{w}$ - the outer diameter $[\mathrm{m}]$ and the inner diameter $[\mathrm{m}]$ respectively of the head sleeve, $h_{p o}, h_{p m}$ - piston position [mm] corresponding to the beginning of opening the passage to the atmosphere (allowing for plate seal deformation) and position $[\mathrm{mm}]$ in which the flow field attains the maximum value, respectively.

The following relationship exist between the displacement $h_{p}$ of control piston 1and the displacement $h_{v}$ of head 2:

$$
h_{v}=\left\{\begin{array}{cc}
0 & h_{p} \leq h_{o} \\
h_{p}-h_{o} & h_{p}>h_{o}
\end{array}\right.
$$

where: $h_{o}-$ the maximum distance (clearance) $[\mathrm{m}]$ between head 2 and piston 1 in the upper extreme position.

The mechanical components of a brake valve can be considered as a dynamical system with two degrees of freedom. The equation of motion of tappet 3 and its associated elements being under the action of external forces, has the following form:

$$
m_{t} \frac{d^{2} h_{t}}{d t^{2}}=F_{p t}-F_{s t}+F_{f t}
$$

where: $m_{t}-$ the reduced mass $[\mathrm{kg}]$ of all drive elements from the brake pedal to the tappet; $h_{t}-$ tappet displacement $[\mathrm{m}] ; F_{s t}-$ the action force $[\mathrm{N}]$ of rubber spring $6 ; F_{f t}-$ total friction force $[\mathrm{N}] ; F_{p t}-$ force $[\mathrm{N}]$ applied to the tappet coming from the brake pedal force $F_{p}$, as calculated from the formula:

$$
F_{p t}=F_{p} i_{p} \eta_{p}
$$

where: $i_{p}, \eta_{p}$ - the force ratio and efficiency ratio of the mechanical between the treadle and the tappet, respectively.

The positioning force $F_{s t}$ of rubber spring 6 depends on its deformation $\delta=h_{t}-h_{p}$, and can be described by the third-degree equation:

$$
F_{s t}=c_{1} \delta+c_{2} \delta^{2}+c_{3} \delta^{3}
$$

where: $c_{1}, c_{2}, c_{3}$ - coefficients determined from the approximation of the experimental curve $F_{s t}(\delta)$.

A more complex relationship for $F_{s t}$ can be found in study [29] Taking into account the preload spring force adjustment in the model, the initial condition $h_{t}(0)=h_{t 0} \neq 0$ is taken, while the preload force may not lead to a loss of contact between piston 1 and the valve housing: $h_{p}(0) \approx 0$.

It is assumed that the total friction force has a constant component being dependent on the poppet speed:

$$
F_{f t}=-\operatorname{sgn}\left(\frac{d h_{t}}{d t}\right) \cdot\left(F_{c t}+k_{v t} \frac{d h_{t}}{d t}\right)
$$

where: $F_{c t}-$ fixed value friction force $[\mathrm{N}] ; k_{v t}-$ viscous friction coefficient $[\mathrm{Ns} / \mathrm{m}]$.

The equation of motion of control piston 1 (without the housing action force) has the following form:

$$
m_{z} \frac{d^{2} h_{p}}{d t^{2}}=F_{p 2 a}+F_{s t}+F_{s p}+F_{v}+F_{f p}
$$

where: $m_{z}$ - reduced mass $[\mathrm{kg}]$ of the elements moving together with piston $1 ; F_{p 2 a}-$ pressure force $[\mathrm{N}]$ acting on the piston; $F_{s t}-$ rubber spring 6 action force $[\mathrm{N}] ; F_{s p}$ - piston return spring 5 force $[\mathrm{N}] ; F_{f p}$ - force $[\mathrm{N}]$ of piston 1 friction against the housing; $F_{v}-$ force $[\mathrm{N}]$ of head 2 pressure on piston 1 .

The reduced mass of the elements moving together with the piston is:

$$
m_{z}=\left\{\begin{array}{cl}
m_{p}+m_{s p} / 4 & h_{p} \leq h_{o} \\
m_{p}+m_{v}+\left(m_{s p}+m_{s v}\right) / 4 & h_{p}>h_{o}
\end{array}\right.
$$


where: $m_{p}-$ mass $[\mathrm{kg}]$ of control piston $1 ; m_{v}-$ mass $[\mathrm{kg}]$ of head 2 with the sleeve guide; $m_{s v}-$ mass $[\mathrm{kg}]$ of spring 4 clamping head 2 ; $m_{s p}-$ mass $[\mathrm{kg}]$ of return spring 5 .

The force of pressure acting on the pistons is:

$$
F_{p 2 a}=\frac{\pi D_{p}^{2}}{4} p_{a}-\frac{\pi D_{s p}^{2}}{4} p_{a}-\frac{\pi\left(D_{p}^{2}-D_{s p}^{2}\right)}{4} p_{2}=-\frac{\pi\left(D_{p}^{2}-D_{s p}^{2}\right)}{4}\left(p_{2}-p_{a}\right)
$$

The force of return spring 5 pressure on piston 1 is calculated from the relationship:

$$
F_{s p}=-\left(F_{s p o}+c_{p} h_{p}\right)
$$

where: $F_{\text {spo }}-$ spring 5 preset force $[\mathrm{N}]$ for $h_{p}=0[\mathrm{~N}] ; c_{p}-$ stiffness $(\mathrm{N} / \mathrm{m})$ of spring $5[\mathrm{~N} / \mathrm{m}]$.

When determining the relationship for the force $F_{v}$ of head pressure on the piston, it was assumed that the poppet valve had an unladen design $\left(D_{s p} \approx D_{z}\right)$, thus the relationship is:

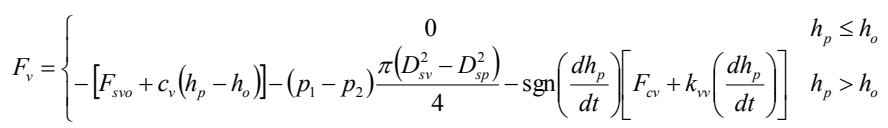

where: $D_{z}$ - head sleeve guide diameter [m]; $F_{c v}$ - head guide kinematic friction force $[\mathrm{N}] ; k_{v}$ - viscous friction coefficient $[\mathrm{Ns} / \mathrm{m}]$.

The force of static and kinetic friction of piston 1 against the housing is described using the Karnopp model [1] according to:

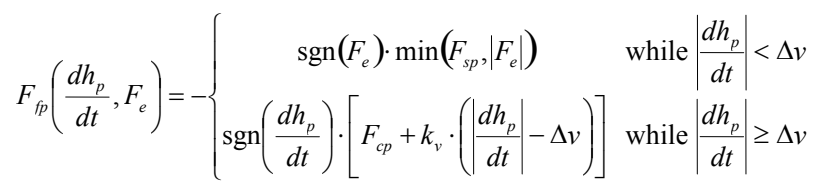

The total static friction force $F_{s p}$ and kinetic friction force $F_{c p}$ of piston 1 , as well as the kinetic friction force $F_{c v}$ of the guide of head 2, are described by the relationships:

$$
\begin{gathered}
F_{s p}=\pi D_{p}\left(f_{s}+k_{s}\left|p_{2}-p_{a}\right|\right) \\
F_{c p}=\pi D_{p}\left(f_{c}+k_{c}\left|p_{2}-p_{a}\right|\right) \\
F_{c v}=\pi D_{z}\left(f_{c}+k_{c}\left|p_{1}-p_{a}\right|\right)
\end{gathered}
$$

where: $f_{s}, f_{c}-$ static friction force $[\mathrm{N} / \mathrm{m}]$ and kinetic friction force $[\mathrm{N} / \mathrm{m}]$, respectively, per unit piston perimeter, independent of the differential pressure across the piston; $k_{s}, k_{c}$ - proportionality factors [m].

Based on the energy conservation law for open systems [3], excluding the kinetic and potential energies, equations for the change in the internal energy of air in the control volumes $V_{l}$ and $V_{2}$ of the chamber are obtained in the following form:

$$
\begin{gathered}
\frac{d U_{1}}{d t}=\dot{Q}_{1}+\dot{H}_{1}-\dot{H}_{1-2} \\
\frac{d U_{2}}{d t}=\dot{Q}_{2}+\dot{W}_{2}+\dot{H}_{1-2} \mp \dot{H}_{2}-\dot{H}_{2-3}
\end{gathered}
$$

where: $U_{i}$ - internal energy [J] of air in the i-th chamber; $\dot{H}_{i}-$ enthalpy of the fluxes $[\mathrm{W}]$ flowing to or from a particular chamber; $\dot{W}_{i}$ - rate of external work done by air in the $i$-th chamber [W]; $\dot{Q}_{i}$ - heat flux $[\mathrm{W}]$ exchanged between the $i$-th chamber air and the environment:

$$
\begin{aligned}
& U_{i}=m_{V i} \cdot c_{v} T_{i} \quad \dot{H}_{i}=\dot{m}_{i} c_{p} T_{m i} \\
& \dot{W}_{i}=-p_{i} \cdot \dot{V}_{i} \quad \dot{Q}_{i}=\alpha_{i} \cdot A_{w}\left(T_{w}-T_{i}\right)
\end{aligned}
$$

where: $c_{v}, c_{p}$ - specific heat capacity of the gas at a constant volume and pressure: $c_{v}=717 \mathrm{~J} /(\mathrm{kgK}), c_{p}=1005 \mathrm{~J} /(\mathrm{kgK}) ; T_{i}$ - temperature $[\mathrm{K}]$ of the $i$-th chamber air; $m_{V i}$ - mass of the $i$-th chamber air $[\mathrm{kg}] ; T_{m i}-$ flux temperature $[\mathrm{K}]$ (for the flux flowing out from the chamber, $T_{m i}$ $\left.=T_{i}\right) ; T_{w}$ - valve housing wall temperature $[\mathrm{K}]$ equal to ambient temperature; $\alpha_{i}$-heat transfer coefficient $\left[\mathrm{W} /\left(\mathrm{m}^{2} \mathrm{~K}\right)\right]$ of the $i$-th chamber; $A_{i}$-internal surface area $\left[\mathrm{m}^{2}\right]$ of the $i$-th chamber, being dependent on the piston displacement, similarly as the volume $V_{i}\left[\mathrm{~m}^{3}\right]$.

After differentiation of the internal energy:

$$
\frac{d U_{i}}{d t}=c_{v}\left(\frac{d m_{V i}}{d t} T_{i}+m_{V i} \frac{d T_{i}}{d t}\right)
$$

and using the equation of state of an ideal gas in the chamber $V_{i}$ (as formulated in a differential form):

$$
p_{i} \frac{d V_{i}}{d t}+V_{i} \frac{d p_{i}}{d t}=R\left(\frac{d m_{V i}}{d t} T_{i}+m_{V i} \frac{d T_{i}}{d t}\right)
$$

the following has been obtained:

$$
\frac{d U_{i}}{d t}=\frac{c_{v}}{R}\left(p_{i} \frac{d V_{i}}{d t}+V_{i} \frac{d p_{i}}{d t}\right)
$$

Using the relationship $R / c_{v}=\kappa-1$ and combining equations (22), (23) and (27) leads to the following differential equations for air pressure variation in the brake chamber $V_{I}$ and the valve chamber $V_{2}$ :

$$
\begin{gathered}
\frac{d p_{1}}{d t}=\frac{1}{V_{1}}(\kappa-1)\left(\dot{Q}_{1}+\dot{H}_{1}-\dot{H}_{1-2}\right) \\
\frac{d p_{2}}{d t}=\frac{1}{V_{2}}\left[(\kappa-1)\left(\dot{Q}_{2}+\dot{H}_{1-2} \mp \dot{H}_{2}-\dot{H}_{2-3}\right)-\kappa \cdot p_{2} \frac{d V_{2}}{d t}\right]
\end{gathered}
$$

Substituting equations (1) and (2) in equation (26) and calculating the air mass from the ideal gas equation $m_{V i}=\left(p_{i} V_{j}\right) / R T_{i}$, and after making necessary transformations, the following differential equations for air temperature variation in particular brake chambers are obtained:

$$
\begin{gathered}
\frac{d T_{1}}{d t}=\frac{T_{1}}{p_{1} V_{1}}\left[V_{1} \frac{d p}{d t}-R T_{1}\left(\dot{m}_{1}-\dot{m}_{1-2}\right)\right] \\
\frac{d T_{2}}{d t}=\frac{T_{2}}{p_{2} V_{2}}\left[p_{2} \frac{d V_{2}}{d t}+V_{2} \frac{d p_{2}}{d t}-R T_{2}\left(\dot{m}_{1-2} \mp \dot{m}_{2}-\dot{m}_{2-3}\right)\right]
\end{gathered}
$$




\section{Modelling the energy supply unit}

A simplified computational diagram of the energy supply unit of a tractor's pneumatic system is presented in Figure 3. The desired air pressure $p_{t}$ in reservoir 5 is maintained by unloader valve 3 (governor).

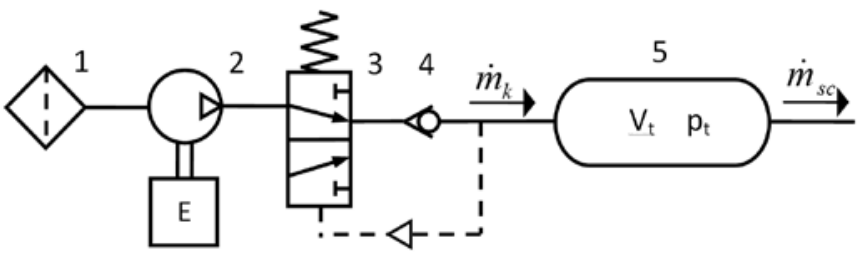

Fig. 3. Computational diagram of an agricultural tractor's pneumatic system energy supply unit: 1 -filter, 2 - compressor, 3 -unloader valve (governor), 4 - check valve, 5 - air reservoir

The increase in pressure up to a maximum preset value $p_{\max }$ makes unload valve 3 switch over, and the air from compressor 2 is forced to the atmosphere (the idle run of the compressor). The pressure drop in the system to the preset minimum value $p_{\min }$ causes the switching over of the unload valve again and re-charging of the system by compressor. This type of unload valve action can be described by the function of a bi-stable relay with a hysteresis loop of the width equal to $p_{\max }-p_{\min }$ :

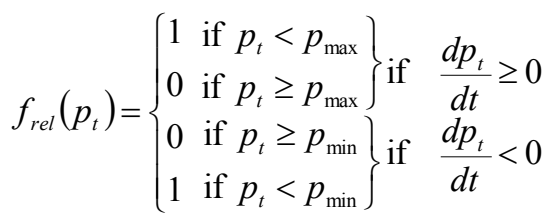

Assuming that the compressor discharge pressure is equal to the reservoir pressure $p_{t}$ (a short length and a small capacity of the pipe connecting the compressor with the reservoir), the mass flux $\dot{m}_{k}$ $[\mathrm{kg} / \mathrm{s}]$ of air discharged by the compressor can be described as follows [16]:

$\dot{m}_{k}\left(n_{k}, p_{t}\right)=f_{r e l} \cdot \eta_{v} \cdot V_{s} \cdot i_{c} \frac{n_{k}}{60} \rho_{a}=f_{r e l} \cdot \eta_{v} \frac{\pi \cdot D_{c}^{2}}{4 \cdot 60} \cdot S \cdot i_{c} \cdot n_{k} \cdot \rho_{a}$

where: $\eta_{v}$ - volumetric efficiency, $V_{s}$ - displacement volume $\left[\mathrm{m}^{3}\right]$, $D_{c}$ - cylinder diameter [m], $S$ - piston stroke [m], $i_{c}-$ number of cylinders, $n_{k}-$ compressor shaft speed $[\mathrm{rpm}], \rho_{a}-$ air density $\left[\mathrm{kg} / \mathrm{m}^{3}\right]$ under ambient conditions.

The value of volumetric efficiency $\eta_{v}$ as dependent on the compressor shaft speed $n_{k}$ and discharge pressure (reservoir pressure $p_{t}$ ) was determined by the non-linear regression method based on the compressor suction capacity curve:

$$
\varsigma_{v}=A_{1}+A_{2} n_{k}+A_{3} n_{k}^{2}+A_{4} p_{t}+A_{5} p_{t}^{2}
$$

where: $p_{t}$ - discharge pressure $[\mathrm{kPa}] ; A_{1} \div A_{5}$ - regression coefficients. For the FOS Polmo 601.23. 924 compressor model (Polmo, 2011): $A_{1}=0.809863 ; A_{2}=0.321974 \cdot 10^{-4} ; A_{3}=-1.19758 \cdot 10^{-8} ; A_{4}=-$ $7.07972 \cdot 10^{-4} ; A_{5}=3.1248 \cdot 10^{-7}\left(\mathrm{R}^{2}=99.39 \%\right.$, MAPE $\left.=1.02 \%\right)$.

Changes in reservoir air pressure and temperature are described by the following equations [16]:

$$
\begin{aligned}
& \frac{d p_{t}}{d t}=\frac{1}{V_{t}}\left[(\kappa-1)\left(\dot{Q}+\dot{H}_{k}-\dot{H}_{s c}\right)\right] \\
& \dot{Q}=\alpha_{t} A_{t}\left(T_{w}-T_{t}\right) \quad \dot{H}_{i}=\dot{m}_{i} c_{p} T_{i}
\end{aligned}
$$

$$
\frac{d T_{t}}{d t}=\frac{T_{t}}{p_{t} V_{t}}\left[V_{t} \frac{d p_{z}}{d t}-R T_{t}\left(\dot{m}_{k}-\dot{m}_{s c}\right)\right]
$$

where: $\dot{m}_{s c}-$ mass flux $[\mathrm{kg} / \mathrm{s}]$ entering the supply and control circuits; $\dot{H}_{k}$ - enthalpy flux [W] from the compressor; $\dot{H}_{s c}$ - enthalpy flux

[W] from the reservoir; $\dot{Q}$ - heat flux [W]; $\alpha_{t}$ - heat transfer coefficient $\left[\mathrm{W} /\left(\mathrm{m}^{2} \mathrm{~K}\right)\right] ; A_{t}-$ heat transfer area $\left[\mathrm{m}^{2}\right] ; T_{w}$ - reservoir wall temperature $[\mathrm{K}] ; T_{t}$ - reservoir air temperature $[\mathrm{K}]$ as estimated from the polytropic equation:

$$
T_{k}=T_{a}\left(\frac{p_{t}}{p_{a}}\right)^{\frac{n-1}{n}}
$$

where: $n$ - polytropic exponent, $n=1.25 \div 1.4[4] ; p_{a}, T_{a}$ - ambient pressure $[\mathrm{Pa}]$ and temperature $[\mathrm{K}]$, respectively.

\section{Examples of experimental and simulation studies}

The important functional and service characteristics of agricultural vehicles are checked within certification tests, product qualification tests or periodical inspections. The proposal for a programme of agricultural tractor approval testing in respect of braking, presented in study [17], includes the performance testing of the service and parking brake systems [6] and air brake system checking, including:

- the unload valve operating range,

- coupling head pressure values,

- air system leakage,

- the capacity of reservoirs,

- air compressor capacity, and

- the control device response time.

The research methodology was developed in accordance with the requirements of the Regulation [9] being prepared by the WGAT (Working Group on Agricultural Tractors) for agricultural and forestry vehicles and the 13 ECE Regulation [8] applicable to road vehicles.

The possibilities of using simulation methods for predicting the functional and service characteristics during the model-based design of tractor air brake systems is shown on the example of testing the capacity of the air compressor and the response time of the control device of a Pronar 320AM tractor. The computer models for all of the tractor pneumatic system components were created as $S$-function graphic subsystems stored in the Matlab program's $m$-files, derived from described algorithms and procedures $[14,16]$.

The obtained experimental and simulation results were used to validate the tractor pneumatic system computer model by using statistical methods. The validation included checking the significance of the differences between the time curves of empirical and simulation pressures in the pneumatic system using the nonparametric Kolmogorov-Smirnov (K-S) test. To eliminate the influence of the integration step-size on the test results, the time interval corresponding to the transitional process was divided into 100 equal parts, thus creating a time vector for which the vectors of the interpolated values of experimental and simulated pressures were calculated using Matlab's 
standard function interp1 [33]. Then, using Matlab's standard function kstest2 [19], the parameter $h$ and the two-sample KolmogorovSmirnov test statistics $k s 2$ were calculated to compare the distributions of values in the two experimental and simulation pressure data vectors. The null hypothesis is rejected $(h=1)$ at the significance level $p$, if:

$$
k s 2>k s(p) \sqrt{\frac{n_{1}+n_{2}}{n_{1} \cdot n_{2}}}
$$

where: $n_{1}, n_{2}$ - number of samples being compared, $k s(p)-$ critical value of the Kolmogorov-Smirnov test; for $k s(0.05)=1.36$ and $n_{l}=n_{2}=101$, condition (39) is satisfied if $k s 2>0.1923$.

The modelling performance was also assessed using the coefficient of determination $R^{2}$ and the mean absolute percentage error (MAPE), defined as [35]:

$$
\begin{gathered}
R^{2}=100\left(1-\frac{\sum_{i=1}^{n}\left(p_{m i}-p_{i}\right)^{2}}{\sum_{i=1}^{n}\left(p_{i}-\bar{p}\right)^{2}}\right) \\
M A P E=\frac{100}{n} \sum_{i=1}^{n}\left|\frac{p_{m i}-p_{i}}{p_{i}}\right|
\end{gathered}
$$

where: $n$-number of values in each of the sets, $p_{i}$ - measured values of the feature tested, $p_{m i}$ - corresponding values determined from the model, $\bar{p}$-average measured pressure value.

\subsection{Testing of compressor capacity}

The experimental and simulation tests of compressor capacity during the operation of the tractor pneumatic system consisted in the recording of pressure variations during compressed air charging of an additional reservoir supplied through the towing vehicle's feed circuit. The time to fill the reservoir representing the capacity of the towed vehicle's air brake system was measured from the moment of starting a hot engine until reaching the prescribed pressure at the maximum engine speed. The additional reservoir volume was calculated from the relationship:

$$
V=20 \frac{M_{t}}{p_{\max }}
$$

where: $M_{t}$ - the permissible maximum load [t] per all axles of the towed vehicle or semi-trailer, $p_{\max }-$ maximum regulated pressure value [bar].

For the Pronar 320AM tractor designed for towing trailers of a mass of $M_{t}=3.5 \mathrm{t}$, a volume variation range of $V=8.75 \div 11.1 \mathrm{dm}^{3}$ is obtained, which depends on the adopted pressure $p_{\max }(8$ bar in the dual-line braking system or $6.3 \mathrm{bar}$ in the single-line braking system).

Example results of the simulation (solid lines) and experimental (dashed lines) tests of the Pronar 320AM tractor during filling the reservoir with a volume of $V=10.42 \mathrm{dm}^{3}$ at an engine speed of about $3000 \mathrm{rpm}$ is shown in Figure 4.

The agreement between the experimental $p_{v e}$ and simulated $p_{v}$ reservoir pressure transients was confirmed by the results of the Kolmogorov-Smirnov test $(h=0, k s 2=0.0198<0.1923)$. The adequacy of

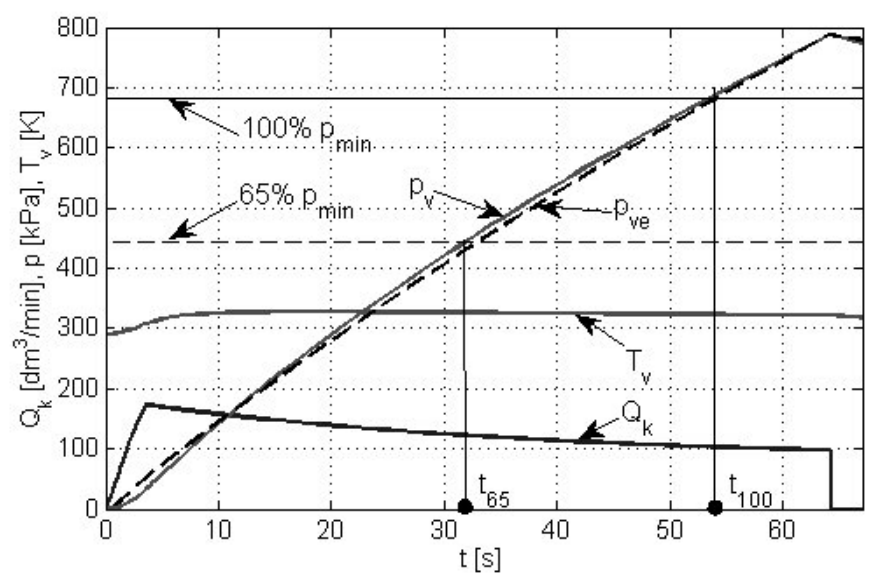

Fig. 4. Results of the simulation test of operation of the Pronar 320AM tractor's pneumatic system energy supply unit, carried out to check the compressor capacity: $Q_{k}$ - compressor capacity rate, $p_{v} ; T_{v}-$ reservoir air pressure and temperature; $p_{v e}-$ experimental pressure $\left(R^{2}=99.83 \%, M A P E=2.47 \%, K-S\right.$ test results: $\left.h=0, k s 2=0.0198\right)$

the computer model was also confirmed by the obtained values of the statistical indicators $R^{2}=99.83 \%$ and MAPE $=2.47 \%$.

Then, based on the time variation of reservoir pressure, the time $t_{65}$ required for the pressure to rise from zero to $65 \%$ of the minimum preset value $\left(p_{\min }=6.83 \mathrm{bar}\right)$ and the time $t_{100}$ needed for reaching $100 \%$ of the minimum preset value were determined. The time values of $t_{65}=33.023 \mathrm{~s}$ and $t_{100}=54.104 \mathrm{~s}$ obtained from experimental tests and of $t_{65}=31.898 \mathrm{~s}$ and $t_{100}=53.519 \mathrm{~s}$ obtained from the simulation tests (with a relative terror of $3.38 \%$ and $1.08 \%$, respectively) are significantly shorter than the maximum values, i.e. 360 and $540 \mathrm{~s}$ respectively, allowable for tractors designed for towing vehicles. The results of the experimental and simulation studies have confirmed the correctness of selection of the compressor for the tractor energy supply unit.

\subsection{Testing of the response time}

The response time of the tractor's dual-line pneumatic system control circuit was determined based on the changes in the brake pedal force and pressure measured at the end of a $2.5 \mathrm{~m}$-long $13 \mathrm{~mm}$ internal diameter line of (an imitation of the trailer control line) connected to the brake coupling (Figure 1). At the beginning of each test, the energy supply unit pressure was equal to the pressure at which the governor restores the feed to the system (the minimum preset value $\left.p_{\min }\right)$. For this test, a pressure vessel with a capacity of $0,385 \pm 0,005$ $\mathrm{dm}^{3}$ was connected to the supply coupling. The volume of this vessel corresponds to the internal volume of a $2.5 \mathrm{~m}$-long $13 \mathrm{~mm}$-internal diameter pipe at a pressure of 6.5 bar.

A computer model of the tractor pneumatic system, developed within the Matlab-Simulink program for the study of the transition processes in the control device (corresponding to the diagram in Figure 1), is shown in Figure 5.

The actual input signal in the form of the brake pedal force $F_{p}$ and the actual response signal of the system, including the variations of pressure $p_{t e}$ in the reservoir 4 (Figure 1), pressure $p_{s e}$ in vessel 13 and pressure $p_{c e}$ at the end of line 14 connected to brake coupling head 10, were input to the computer model in the form of FromFile-type source blocs. Examples of simulation (solid lines) and experimental (dashed lines) results obtained during testing of the response time of the Pronar 320AM tractor pneumatic system control circuit are shown in Figures 5 and 6.

The consistence between the experimental $p_{c e}$ and simulated $p_{c}$ pressure transients was confirmed by the results of the Kolmogorov- 


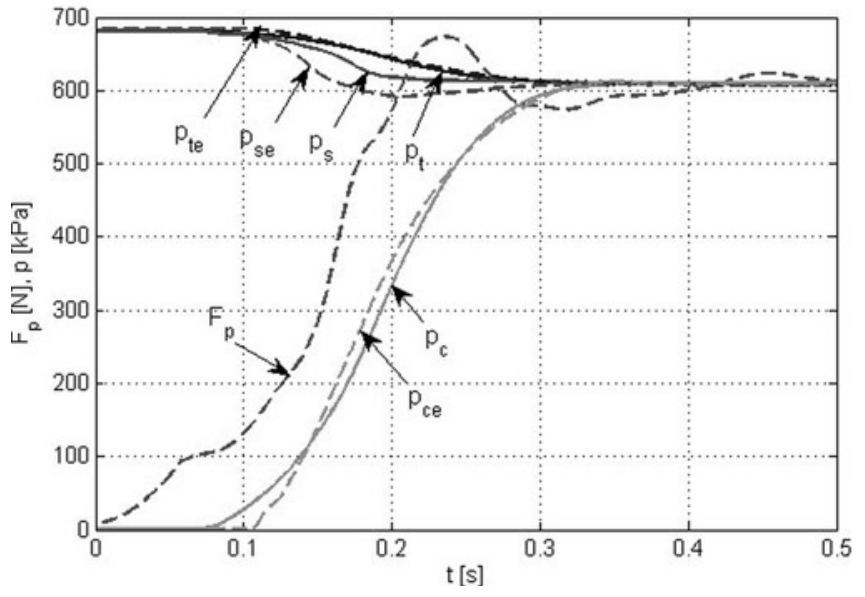

Fig. 5. Results of the experimental and simulation tests of the Pronar MTZ 320 AM tractor control circuit: $p_{t}, p_{s}, p_{c}$ - simulated pressure in the air reservoir, in the vessel connected to the supply coupling head, and at the end of the control line, respectively; $p_{t e}, p_{s e}, p_{c e}$-experimental pressure at the same places, $F_{p}$-force measured on the brake pedal $\left(R^{2}=99.24 \%\right.$, MAPE $=16.43 \%, K$-S test results: $h=0, k s 2=0.0990,101$ points)

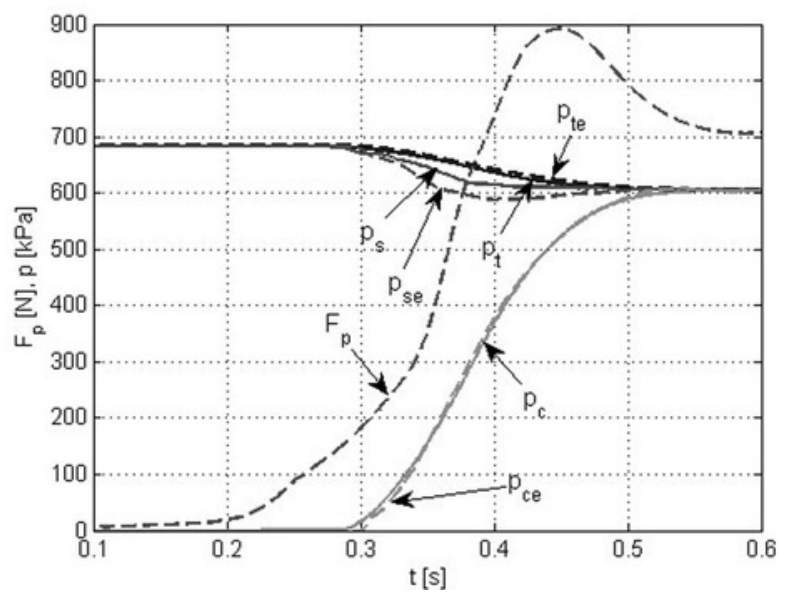

Fig. 6. Results of the experimental and simulation tests of the Pronar MTZ 320 AM tractor control circuit: $p_{t}, p_{s}, p_{c}$ - simulated pressure in the air reservoir, in the vessel connected to the supply coupling head, and at the end of the control line, respectively; $p_{t e}, p_{s e}, p_{c e}$-experimental pressure at the same places, $F_{p}$-force measured on the brake pedal $\left(R^{2}=99.84 \%, M A P E=7.21 \%, K-S\right.$ test results: $h=0, k s 2=0.0396,101$ points)

Smirnov test and by the values of the $R^{2}$ and MAPE indicators (the results are provided in the captions to the figures).

Then, based on the recorded experimental variations of force $F_{p}$ and pressure $p_{c e}$, the response time $t_{r}$, i.e. the time for reaching $10 \%$ and $75 \%$ of the asymptotic pressure value, was determined as a function of the brake pedal actuation time $t_{f}$, starting from the shortest possible actuation times and then gradually increasing them up to a time of about 0.4 seconds.

After determining the linear regression equations of response times $t_{10}$ and $t_{75}$ as a function of the time $t_{f}$ of pedal brake force variations (Figure 7) by least squares method, the response time for rapid braking corresponding to an actuation time of $t_{f}=0.2$ was calculated. The results of calculation of the pneumatic system control device response time, as obtained from the experimental tests, are summarized in Table 1.

For the determination of the response time by the digital simulation method, the computer model shown in Figure 5 was used after inputting the brake pedal force $F_{p}$ standard signal, i.e. the one ramping from 0 to a maximum of $600 \mathrm{~N}$ for a duration of $0.2 \mathrm{~s}$. The simulation

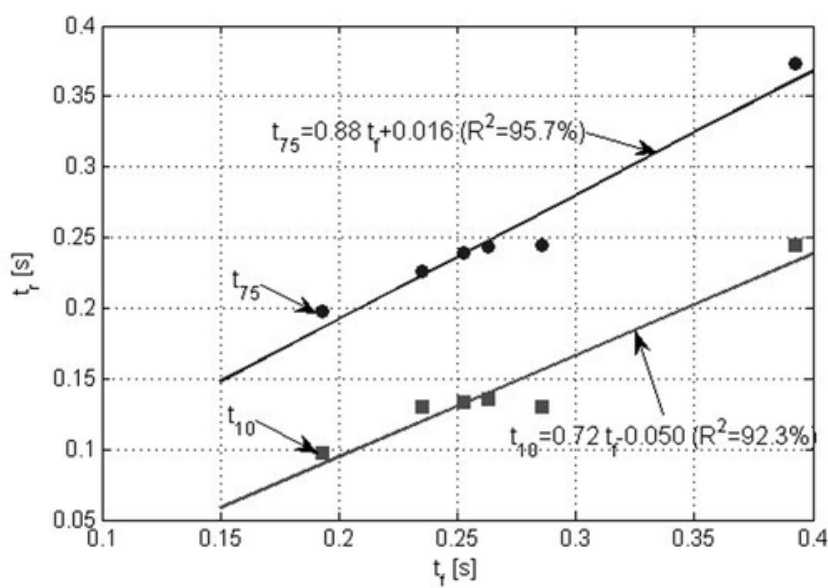

Fig. 7. Relation between the response time $t_{r}\left(t_{10}\right.$ and $\left.t_{75}\right)$ and the actuation time $t_{f}$ (experimental results)

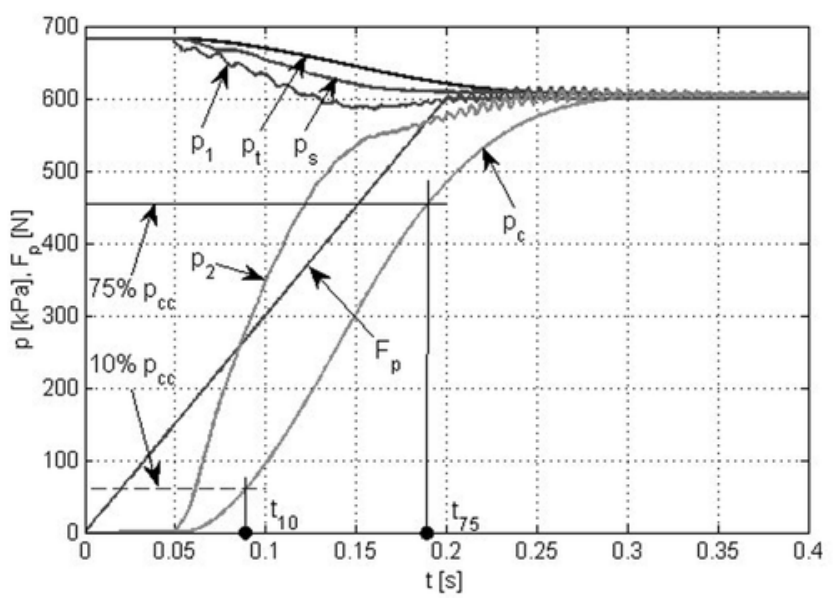

Fig. 8. The results of simulation test of reaction time $t_{r}$ for the standard course of force $F_{p}$

results are shown in Figure 8. The values of the response times $t_{10}$ and $t_{75}$, as determined based on the pressure $p_{c}$ variation, are given in Table 1.

It follows from the experimental and simulation studies that the obtained response time values are significantly lower than the permissible values $t_{10}=0.2$ and $t_{75}=0.4 \mathrm{~s}$, which indicates the correct choice of the elements shaping the dynamic characteristics of the tractor pneumatic system. The determined relative error of the response time does not exceed 5\%, indicating a satisfactory accuracy of the computer model for the modelling purpose.

Table 1. Response time [s] of the control circuit for $10 \%$ and $75 \%$ of the asymptotic pressure

\begin{tabular}{||c|c|c|c|c||}
\hline & Requirements & Experiment & Simulation & Relative error \\
\hline $\mathrm{t}_{10}$ & $\leq 0.2$ & 0.094 & 0.0893 & $5.00 \%$ \\
\hline $\mathrm{t}_{75}$ & $\leq 0.4$ & 0.192 & 0.1896 & $1.25 \%$ \\
\hline \hline
\end{tabular}

\section{Conclusions}

The developed computer model can be used to predict, by simulation methods, selected functional and service characteristics in the design of the pneumatic system of small- power agricultural tractors equipped with mechanical brakes. The computer model can also serve as a subsystem for the study of transient processes in the multi-circuit pneumatic braking system of a tractor-trailer unit with the aim of shaping the desired dynamic properties, including the speed and synchrony of action (brake compatibility). 
The obtained values of the statistical indicators $R^{2}, M A P E$, as well as the results of the Kolmogorov-Smirnov test assessing the consistence between the experimental and simulation pressure transients during testing of the compressor capacity and control circuit response time have confirmed the adequacy of the Pronar 320AM tractor pneumatic system computer model implemented in Matlab-Simulink. The studies have also shown the correctness of selection of the compressor capacity and the high speed of operation of the control device in terms of the requirements imposed.
The mathematical model of the supply unit and the trailer control valve can be used for modelling other commercial vehicle pneumatic braking systems. Based on the described trailer control valve model equations, mathematical and computer models for other braking valves of similar construction can be created, while considering heat transfer, the inertial forces of valve moving parts, and static and kinetic friction forces.

This research was sponsored by Rector's project no. S/WM/2/2013.

\section{References}

1. Armstrong-Helouvry B., Dupont P., Canudas de Wit C. A survey of models analysis tools and compensation methods for the control of machines with friction. Automatica 1994; 30(7): 1083-1138, http://dx.doi.org/10.1016/0005-1098(94)90209-7.

3. Beater P. Pneumatic Drives. System Design, Modeling and Control, Berlin, Heidelberg, Springer-Verlag, 2007.

4. Bloch H.P. A Practical Guide to Compressor Technology. John Wiley \& Sons, Hoboken, New Jersey, 2006, http://dx.doi. org/10.1002/0471929786.

5. Breuer B.J., Bill K. H. Brake Technology Handbook (R-375). SAE International, Warrendale. 2008.

6. Czaban J., Kamiński Z. Performance testing of agriculture tractor braking systems. Archiwum Motoryzacji 2010; (1): 15-25.

7. Dodd M., Bartlett R., Knight I. Provision of information and services on the subject of the performance requirements, testing methods and limit values for braking systems of agricultural and forestry tractors, their trailers and interchangeable towed machinery - final report. TRL Unpublished Project Report, Wokingham, UK, 2007, No. UPR/VE/064/07,

8. ECE Regulation No. 13. Uniform provisions concerning the approval of vehicles of categories $\mathrm{M}, \mathrm{N}$ and $\mathrm{O}$ with regard to braking. UN Economic Commission for Europe, Geneva, Switzerland, 2001.

9. EEC (2008) Draft Regulation of the European Parliament and the Council on the braking systems of agricultural or forestry tractors, their trailers and interchangeable towed machinery, amending Directive 2003/37/EC, Council Directive 89/173/EEC and repealing Council Directive 76/432/EEC. (17.11.2008) http://circa.europa.eu/Public/irc/enterprise/automotive/library?1=/agricultural_tractors/meeting november_2008/99rev16_v171108pdf/EN_1.0_\&a=d

10. Govindan N., Jayaraman V., Venkatasamy S.R., Ramasamy M. Mathematical modeling and simulation of reed valve reciprocating air compressor. Thermal Science 2009; 13(3): 47-58, http://dx.doi.org/10.2298/TSCI0903047G.

11. He L., Wang X., Zhang Y., Wu J., Chen L. Modeling and Simulation Vehicle Air Brake System. Proceedings 8th Modelica Conference. Dresden, Germany, 2011; March 20-22: 430-435. (https://modelica.org/events/modelica2011/Proceedings/pages/papers/17_3_ID_144_a_ fv.pdf).

12. Kamiński Z. Dynamic calculations of pneumatic relay valve. Acta Mechanica et Automatica 2009; 3(1): 62-64.

13. Kamiński Z. Mathematical modeling of pneumatic relay valve. Hydraulika i Pneumatyka 2009; 5: 22-25.

14. Kamiński Z. Mathematical Modeling of Pneumatic Pipes in a Simulation of Heterogeneous Engineering Systems. ASME Journal of Fluids Engineering 2011; 133(12): 1-8, http://dx.doi.org/10.1115/1.4005261.

15. Kamiński Z. Mathematical Modelling of the Pneumatic Relay Emergency Valve for Dual-line Agricultural Trailer Braking Systems. Proceedings of the Institution of Mechanical Engineers, Part D: Journal of Automobile Engineering 2012; 226(5): 603-612. (http://pid. sagepub.com/content/early/2011/10/11/0954407011423133: 1-9).

16. Kamiński Z. Modelling of the energy supply equipment of the air braking system of a farm tractor. The Archives of Automotive Engineering 2011; 3: 33-39.

17. Kamiński Z., Czaban J. Proposition of exploration program of braking systems of agriculture tractors. MOTROL 2006; 8: 92-100.

18. Kulesza Z., Siemieniako F. Modeling the air brake system equipped with brake and relay valves. Scientific Journals Maritime University of Szczecin 2010; 24(96): 5-11.

19. Martinez W.L., Martinez A.R. Computational Statistics Handbook with MATLAB, 2th edition, Boca Raton, FL: Chapman \& Hall/ CRC, 2008.

20. Metljuk N.F., Avtushko V.P. Dinamika Pnevmaticheskikh Privodov Avtomobilej. Mashinostroenie, Moskva, 1980.

21. Miatluk M., Czaban J. An Analysis of Transient Processes in Pneumatic Brake System with Automatic Regulator of Brake Forces of Automotive Vehicles. Commission of Motorization and Power Industry in Agriculture 2006; 6: 85-93.

22. Miatluk M., Kamiński Z., Czaban J. Characteristic Features of the Airflow of Pneumatic Elements of Agricultural Vehicles. Commission of Motorization and Power Industry in Agriculture 2003; 3: 174-181.

23. Natarajan S.V., Subramanian S.C., Darbha S., Rajagopal K.R. A model of the relay valve used in an air brake system. Nonlinear Analysis: Hybrid Systems 2007; 1(3): 430-442, http://dx.doi.org/10.1016/j.nahs.2006.11.003.

24. Nèmeth H., Ailer P., Hangos K.M. Unified model simplification procedure applied to a single protection valve. Control Engineering Practice 2005; 13(3): 315-326, http://dx.doi.org/10.1016/j.conengprac.2004.03.013.

25. Polmo (2011) Fabryka Osprzętu Samochodowego Polmo" Łódź S.A. Single cylinder compressors. 2011, http://www.polmo-lodz. com.pl/katalog/.

26. Pronar. Tractors. Pronar 320AM. http://www.pronar.pl/ciagniki/__pronar_320am_.html.

27. Radlinski R.W., Flick, M.A. Tractor and trailer brake system compatibility. SAE Transactions, 1986; paper no. 861942.

28. Scarlett A. In-service assessment of agricultural trailer and trailed appliance braking system condition and performance. The Agricultural Trailer Braking Study. 2009; RR697 Research Report, (http://www.hse.gov.uk/research/rrpdf/rr697.pdf). 
29. Subramanian S.C., Darbha S., Rajagopal K.R. Modelling the pneumatic subsystem of a S-cam air brake system. Trans. of the ASME, J. Dynamic Systems, Measurement and Control 2004; 126(1): 36-46, http://dx.doi.org/10.1115/1.1666893.

30. Venkatesan J., Nagarajan G., Seeniraj R.V., Kumar S. Mathematical modeling of water cooled automotive air compressor. International Journal of Engineering and Technology 2009; 1(1): 50-56, http://dx.doi.org/10.7763/IJET.2009.V1.9.

31. Visteon. Foot brake valve. http://www.demont.com.pl/katalog/4113-1i2.pdf

32. Wabco Air-braking system. Agriculture and forestry vehicles. Edition 8 (Version 2/02.2010(en)). www.wabco-auto.com.

33. Yang W.Y., Cao, W., Chung, T. S., Morris J. Applied Numerical Methods Using MATLAB. John Wiley \& Sons, Inc., Hoboken, New Jersey, 2005, http://dx.doi.org/10.1002/0471705195.

34. Zhang H., Wu J., Zhang Y., Chen L. Objected oriented modelling and simulation of pneumatic brake system with ABS. IEEE Intelligent Vehicle Symposium, Xi'an, Shaanxi, China, 2009; June 3-5: 780-785.

35. Zurada J., Levitan A., Guan J. A Comparison of Regression and Artificial Intelligence Methods in a Mass Appraisal Context, Journal of Real Estate Research 2011; 33(3): 349-387.

\section{Zbigniew KAMIŃSKI \\ Krzysztof KULIKOWSKI}

Department of Machine Construction and Exploitation

Faculty of Mechanical Engineering

Białystok University of Technology

ul. Wiejska nr 45C, 15-351 Białystok, Poland

E-mails: z.kaminski@pb.edu.pl, k.kulikowski@doktoranci.pb.edu.pl 